\title{
Impact of Capital Structure on the Performance of Micro Finance Institutions: Evidence from Pakistan
}

\author{
Komal Saeed \\ komal13aug@gmail.com \\ M.Phil. Scholar, School of Accounting and Finance, University of Central Punjab
}

\author{
Areeba Suleman \\ Areeba.suleman@ucp.edu.pk \\ Research Associate, School of Accounting and \\ Finance, University of Central Punjab
}

\author{
ljaz Hussain Bokhari \\ bokhari.ijaz@ucp.edu.pk \\ Lecturer, Scholar, School of Accounting and Finance, \\ University of Central Punjab
}

\begin{abstract}
The purpose of the research is to examine the impact of capital structure on the performance of MFl's in Pakistan. Panel data covering 5 years period 2010-2014 were taken into account within the extension of fixed and random effect techniques. Most of the microfinance institutions with more deposits to assets and higher gross loan portfolio are performing better for the performance but the more debt can reduce the performance according to this study. This is the first study which is showing the picture of only about Pakistan and before it no work has been done on Pakistan's MFI's performance.
\end{abstract}

Keywords: Capital structure, performance, gross loan portfolio, deposits to assets, Micro finance institutions

\section{Introduction}

Background of the study

In developing nations about $90 \%$ people don't have access of financial services like loans or either it is saving; this problem leads towards the reason of "vicious circle of poverty" (Robinson, 2001). Globally many steps have been taken foe the alleviation of poverty in which Micro finance is one of them. Microfinance is not a new concept, its operations started from 1976 by Prof. Muhammad Younus, at that time he was head of Rural Economic plan (REP) at university of Chittagong, and he introduced an action research plan for the poor people to find out the best possible banking system (khan, 2010). It was the first step of microfinance towards popularity after it spreads all over the world from South Asian countries to Africa and Europe also. Earlier there was so many criticism on micro financing but with the passage of time it become the solution of poor people as this factor was eliminating the sense of deprivation and encourages self dependence (Ganesha, 2007). Worldwide used forms of micro financing are Micro credits/loans, Health, Education, Insurance, Asset lending and rural supports etc. Globally Microfinance institutions are providing the micro financial services to those people who have difficult access to banks, it is providing services to people whose income is low, developed countries are using this tool to alleviate poverty (Ismail \& Possumah, 2012). In earlier times, MFI's was determined by Government licensed and NGO's, but currently with new arrivals in the sector, increase the investment structure for funding the MFI's (Goodman, 2008). Currently luckily it is adopted by both government and non government sector. In 1982 Orangi pilot project was first struggle by a local NGO. Dr Hameed Akhtar was the initiator and he has successfully completed his project. In 1982 Agha Khan Rural support program started after which Government started its first Rural support program, the purpose behind this project was to provide Agriculture facilities and for the betterment of their life style. In Pakistan Micro finance Institutions includes Government licensed, Non government organizations and rural support programs, and there are also other types of MFI's but their contribution is lesser. According to Omondi (2003) the study set up that the subsidizing structure utilized by microfinance foundations influences the financial execution of the firm. Debt to equity proportion has a negative relationship with financial performance meaning the more debt a firm utilizes in financing its operations the second rate financial performance it registers. Deposit to resources proportion has a positive relationship with budgetary execution suggesting that the more deposits a microfinance foundation acknowledges the higher the money related execution. According to Pakistan Micro finance review (2014) the main source of funding were deposits by $44 \%$, debt by $33 \%$ and equity was $23 \%$.In Pakistan there were 5.3 million depositors in 2014.

The separation of ownership and control become a critical issue

The current issue and full text archive of this journal is available at http://jraspublications.org/index.php/JRAS/issue/archive Journal of Research in Administrative Sciences (JRAS) IX(I), 26-31, ISSN: 2664-2433 
in modern governance, there is possibility that controller objective varies from owner's objective which can create the agency cost problem; to overcome this problem many solutions have been proposed. One of them is firm's capital structure which is mix of debt and equity. Thus according to the theory high leverage can increase the responsibility of controller to act more for the betterment of owner.

If there is perfect competition in the market then we can ignore the capital structure (Miller, Modigillani, \& H, 1958). The leveraged should be low for poorer borrowers of MFI's (Morduch, 2000). The capital structure has impact on MFI's (Coleman, 2007). Capital structure is the point of attention in microfinance institutions as they generate funds from local government or by international fund. But the more use of subsidized credit for running the operations may exploit the efficiency of performance of MFI's. In many MFI's Microcredit programs the procedure of lending is to increase the size of repeat loans after viewing the previous payment record, it is compulsory to attract more funds for sustainability (Fehr, 2006). Thus donor funding is converting in to the traditional structure of capital financing like corporate sector.

\section{Problem Statement}

More usage of subsidize capital structure for running the operations may exploit the profitability, outreach and sustainability of MFI's

\section{Research Questions}

- What is the role of deposits to total assets in the performance of MFI's?

- What combination of debt and equity will ensure the performance of MFI's?

- Do efficiency leads the performance of MFI's?

- Do sustainability is taking part in the performance of MFI's.

\section{Research objectives}

To examine how the mixture of debt and equity (D/A.D/E and GLP/A) affects the performance of MFI's by taking into account return on assets, return on equity, outreach, Operational self sufficiency an financial self sufficiency.

\section{Significance of the study}

It is important to indicate the studies on Pakistan's economy regarding MFI's performance like (khan, 2010)looked into the critical factors which can influence the Micro finance structure in Pakistan and he also examines the performance analysis of Indian's MFI,s. While analysis the role of capital structure in the Asian MFI.s by taking regional factors has been done (Abrar \& Javaid, 2016). The empirical work on Pakistan's economy is rare regarding the impact of MFI's that's why it is important to identify this process. This study would advantage various gatherings among them directors of MFIs who might utilize the study to pick up a knowledge in the effect of financing structure on the income development of their organizations and how this would thusly offer them some assistance with structuring their capital and financing as it were which conveys more advantage to the shareholders. Besides, microfinance strategists, strategy creators, yearning microfinance specialists, college understudies seeking after a vocation in account are liable to advantage.

\section{Literature Review}

\section{Capital structure And MFI's}

According to the study conduct in Kenya (Omondi, 2013) Researcher was investigating the financial structure relationship with MFI's in Kenya, the purpose behind his study was explore some valued suggestions for the betterment of this sector that is how they can maintain the mix structure and which structure is better for the performance of MFI's he found that Debt to equity ratio has negative impact on the performance which means that more debt can reduce the performance of this sector, for the accomplishment of researcher goal he used descriptive analysis by taking 56 microfinance institutions with data of 5 years (2009-2013). His research further provides another research for the researchers that they can also check the relationship among working capital management and financial performance of
MFI's. As far as important factors of micro finance institutions are concerned (khan, 2010). the researcher aim was to analyze the categories of MFI's and their effectiveness using both approaches institutional approach and welfarists approach, the proxy used for the performance in institutional sense was Profitability and transparency and for welfarists approach outreach and productivity wads used. The contribution behind this study was to critically analyze all the factors which can be a part of performance in this specific industry. Moreover the sample was of 18 MFI's of Pakistan by using the ratio analysis of these institutions. The purpose of researcher was the choice of capital structure on the performance of MFI's in south Asian region. He used the sample of 136 institutes from 2006-2010 for ROA and ROE as dependent variable and $\mathrm{D} / \mathrm{E}$ ratio as independent variable by using multiple regression and person correlation, he found that there is opposite relation between performance and D/E ratio and positive relation between firm performance and gearing of the firm Leon ( 2013). Empirically test the capital structure and financial performance of manufacturing firm in Sri Lanka and founds that leverage and return on equity has negative relationship (Rub, Suleiman, Abbadi, \& Nour, 2012). In this study the researcher was to investigate the relationship between market efficiency and capital structure of Palestinian financial institutions he also founds that leverage has a negative relationship with firm performance.

\section{Hypothesis}

H1: Financial performance is significantly affected by debt to equity (H1a), D_A (H1b), GLP_A (H1c).

H1: Sustainability is significantly affected by debt to equity (H2a), D_A (H2b), GLP_A (H2c).

H3: Outreach is significantly affected by debt to equity (H3a), D_A (H3b), GLP_A (H3c)

\section{Theoretical perspective}

Modigliani-Miller Theorem: This theory is relevant where the capital structure is irrelevant. This theory is for the real world having no taxes no bankruptcy costs no profitability no cost related to any factor by relaxing the assumption many theories came in to existence which include Trade- off theory pecking order theory. Agency cost theory (Ronoh, 2015). The reason for review of theory is to take performance as dependent variable. It explains that under classic random walk, financial performance does not influenced by how the firm is financed.

\section{Trade-off theory}

According to the trade off theory the optimal capital structure can be determined through tradeoff between the corporate and personal taxes, bankruptcy cost and agency cost. The debt benefit provide tax shield to the corporations "reduction of agency cost through the threat of liquidation which causes personal losses to managers of salaries, reputation, perquisites" According to (Mayers, 1984)"the tradeoff theory justifies moderate debt ratios. It says that the firm will borrow up to the point where the marginal value of tax shields on additional debt is just offset by the increase in the present value of possible costs of financial distress. Financial distress refers to the costs of bankruptcy or reorganization, and also to the agency costs that arise when the firm's creditworthiness is in doubt"

The purpose behind this theory was to take D/E and deposits is independent variable. As this theory emphasize that managers always prefer debt over equity.

Agency cost theory: explains that the shareholder inertest and managers interest are not same there is also need to take care about equity that's why researcher reviewed this to take Equity as dependent variable as this theory states that "conflicts of interest exert pressure on managers (agents) to seek equity even when profitable growth opportunities do not exist."

\section{Conceptual Framework}

According to (huberman, 1994) conceptual framework is a graphical representation of dependent and independent variables may be in written, oral or in narrative form. 
Capital Structure (IV)<smiles></smiles>

\section{Debt to Equity}

Deposit to Asset Ratio Loan portfolio to Asset Ratio
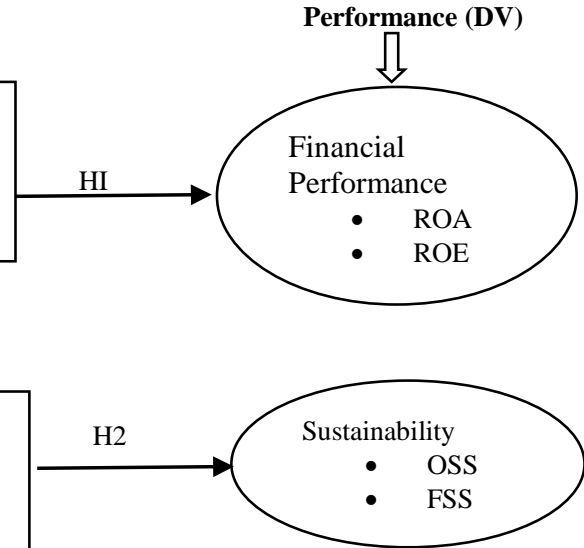

Loan portfolio to Asset Ratio
Debt to Equity

Deposit to Asset Ratio

Loan portfolio to Asset Ratio

Loan portfolio to Asset

Ratio

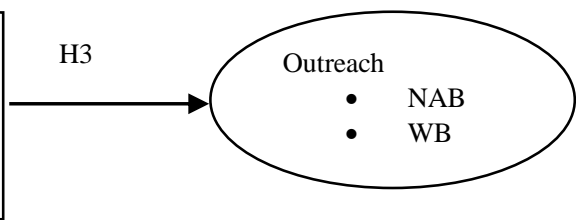

Figure 1: Conceptual frame work

Table 1

\begin{tabular}{lll}
\hline Variables & Description & Formula \\
\hline ROA & Return on assets & Net operating income-taxes/average total assets \\
ROE & Return on equity & Net operating income-taxes/average total equity \\
WB & Women Borrowers & Total number of women borrowers \\
NAB & Number of active borrowers & Total number of active borrowers \\
D/E & Debt to Equity & Total debt /Total assets \\
Dep/T.A & Depositors to total assets & Total number of deposits/total assets \\
Glp/T.A & Gross loan portfolio/total assets & Gross loan portfolio/total assets \\
OSS & Operational; self sufficiency & $\begin{array}{l}\text { Financial Revenue/Financial Expense + Impairment losses on loan }+ \text { Operating } \\
\text { expenses }\end{array}$ \\
& & Adjusted financial Revenue/ adjusted(Financial expenses + Impairment losses on loans \\
FSS & Financial self sufficiency & + operating Expenses) \\
\hline
\end{tabular}

\section{Methodology}

In analyzing the impact of capital structure on the performance of microfinance institutions, philosophical background was positivism and secondary data has been used by using a quantitative design and data has been taken from all 42 MFI's of Pakistan, panel data econometrician technique both with fixed and random effect are used after checking the Probability of Housman Test. There was no need for the sampling as there are few MFI's in Pakistan because in India there was 97 MFI's in 2014 (khan, 2010). MFI's includes banks, NGO's and rural support program. The major source of data was the annual assessment review report on Microfinance sector by Micro finance network.

\section{Analytical model}

\section{Financial performance}

The financial performance of MFI's can be measured through ROA and ROE as indicated in MIX market. The following model may represent the FEM.

Fin performance $=B_{1+} B_{2 i t} D / E+B_{3 i t}$ Dep $/ T . A+B_{4 i t} G L P / T . A+$ $\mu$

\section{Results}

It can be further return as

$R O A=B_{1+} B_{2 i t} D / E+B_{3 i t} D e p / T . A+B_{4 i t} G L P / T . A+\mu_{i t}$ $R O E=B_{l+} B_{2 i t} D / E+B_{3 i t} D e p / T . A+B_{4 i t} G L P / T . A+\mu_{i t}$

Sustainability: Sustainability is tool to measure the how much a particular sector will run its operation in the long run period which is has further many dimensions but here only OSS and FSS has been used.

Sustainability $=B_{1+} B_{2 i t} D / E+B_{3 i t} D e p / T . A+B_{4 i t} G L P / T \cdot A+\mu_{i t}$ Can be written as

$O S S=B_{1+} B_{2 i t} D / E+B_{3 i t} D e p / T . A+B_{4 i t} G L P / T . A+\mu_{i t}$

$F S S=B_{1+} B_{2 i t} D / E+B_{3 i t}$ Dep/T.A+B $B_{4 i t} G L P / T . A+\mu_{i t}$

Outreach

Outreach means how far this particular sector reached and the below indicators have been chosen from the MIX market which are $\mathrm{NAB}$ and $\mathrm{WB}$.

Outreach $=B_{1+} B_{2 i t} D / E+B_{3 i t}$ Dep/T.A+B $B_{4 i t} G L P / T . A+\mu_{i}$

Clearer model is

$N A B=B_{1+} B_{2 i t} D / E+B_{3 i t} D e p / T . A+B_{4 i t} G L P / T . A+\mu_{i t}$

$W B=B_{1+} B_{2 i t} D / E+B_{3 i t} D e p / T . A+B_{4 i t} G L P / T . A+\mu_{i t}$

Table.2

Descriptive Statistics of Variables for MFI's of Pakistan

\begin{tabular}{|c|c|c|c|c|c|c|c|c|c|}
\hline & D_E & DEP_T_A & FSS & GLP_TA & NAB & OSS & ROA & ROE & WB \\
\hline Mean & 1.682353 & 0.410176 & 0.833676 & 0.420912 & 135781.5 & 1.019235 & -0.006265 & -0.026029 & $\begin{array}{c}42211.62 \\
31647.00\end{array}$ \\
\hline Maximum & 7.600000 & 0.848000 & 1.308000 & 0.808000 & 468638.0 & 1.327000 & 0.045000 & 0.290000 & 225048.0 \\
\hline Minimum & 0.000000 & 0.000000 & 0.002000 & 0.030000 & 1121.000 & 0.316000 & -0.350000 & -2.297000 & 80.00000 \\
\hline Std. Dev. & 2.157365 & 0.306852 & 0.364474 & 0.192266 & 139172.2 & 0.218381 & 0.067621 & 0.424003 & 48922.27 \\
\hline
\end{tabular}


Observations $\quad 34$

34

34

34

34

34

$34 \quad 34$

Descriptive statistics shows both dependent and independent variable in above table. It testifies that mean debt to equity is at $168 \%$, however deposits to total assets ratio is $41 \%$. While the FSS is $83 \%$, and the Gross loan portfolio to total assets is at

$42 \%$. Moreover the number of active borrowers and OSS are $135782,1019 \%$ respectively at their mean level. However the Return on asset and Return on equity mean are $-0.6 \%,-2 \%$ respectively.

Table.3

\begin{tabular}{|c|c|c|c|c|c|c|c|c|c|}
\hline Correlation & D_E & DEP_T_A & DEP_T_A & FSS & GLP_TA & NAB & OSS & ROA & ROE \\
\hline D_E & 1.000000 & & & & & & & & \\
\hline DEP_T_A & 0.023588 & 1.000000 & 1.000000 & & & & & & \\
\hline FSS & 0.132588 & 0.247018 & 0.247018 & 1.000000 & & & & & \\
\hline GLP_TA & 0.379629 & 0.269869 & 0.269869 & 0.369576 & 1.000000 & & & & \\
\hline NĀB & 0.287184 & 0.142329 & 0.142329 & 0.292447 & 0.731814 & 1.000000 & & & \\
\hline OSS & 0.136593 & 0.192703 & 0.192703 & 0.473062 & 0.545879 & 0.529452 & 1.000000 & & \\
\hline ROA & -0.022425 & 0.173517 & 0.173517 & 0.419472 & 0.250894 & 0.366370 & 0.824452 & 1.000000 & \\
\hline WB & 0.394213 & 0.056033 & 0.230031 & 0.707863 & 0.906780 & 0.442618 & & 0.314145 & \\
\hline ROE & -0.08162 & 0.171026 & 0.406706 & 0.144183 & 0.287249 & 0.732506 & & 0.974951 & 1.000000 \\
\hline
\end{tabular}

With the help of correlation matrix it is easy to know about the direction and degree of correlation among the variables which are explained above in table.3. The matrix is showing that there is no harmful effects of multi collinearity among the variables as the most of the values are less than $80 \%$.

\section{Hypothesis Testing:}

H1: Financial performance is significantly affected by debt to equity (H1a), D_A (H1b), GLP_A (H1c)

Table 4

Dependent Variable: ROE (Method: Panel EGLS (Cross-section random effects)

\begin{tabular}{|c|c|c|c|c|}
\hline Variable & Coefficient & Std. Error & $\mathrm{t}$-Statistic & Prob. \\
\hline \multicolumn{5}{|l|}{ Prob[F-stat $]=$} \\
\hline \multicolumn{5}{|c|}{ R-Squared $=0.682535$} \\
\hline $\mathrm{C}$ & -0.212463 & 0.072492 & -2.930855 & 0.0068 \\
\hline D_E & -0.040953 & 0.006299 & -6.501113 & 0.0000 \\
\hline LOG(DEP_T_A) & -0.043305 & 0.023946 & -1.808454 & 0.0817 \\
\hline GLP_TA & 0.607780 & 0.133255 & 4.561034 & 0.0001 \\
\hline
\end{tabular}

Here by taking the return on equity as dependent variable as it represent the financial performance of MFI's and other three variables as independent variables of capital structure it can assume that the fitted model is good fit as the value of probability of F-stat is less than 0.05 which means that we are $95 \%$ assure that our model is good fit. While only two variables are significant as $\mathrm{p}$ value of $\mathrm{t}$-stat is less than 5\% in D_E and GLP_TA. However due to not linearity of variables log has been taken of DEP_T_A and it significant at $10 \%$ of p-value. The
GLP TA shows positive relation with ROE which means that GLP from the total assets has positive significant impact on the profitability of firm the more gross loan portfolio the more will be the profitability. The regression coefficient shows that if we will increase D_E ratio by $1 \%$ it will decrease the ROE by $.04 \%$. Similarly if we will increase the DEP_T_A by $100 \%$ it will brings $43 \%$ decline in ROE. However the increase in GLP_TA by $100 \%$ it will positively increase the ROE by $60 \%$.

Table 5

Dependent Variable: ROA (Method: Panel EGLS (Cross-section random effects))

\begin{tabular}{|c|c|c|c|c|}
\hline Variable & Coefficient & Std. Error & t-Statistic & Prob. \\
\hline Prob[F-stat] = 0.000001 & \multicolumn{5}{|l|}{} \\
\hline R-Squared = 0.680086 & -0.076291 & 0.011665 & -6.540111 & 0.0000 \\
\hline C & -0.003541 & 0.001568 & -2.258727 & 0.0322 \\
\hline D_E & -0.013374 & 0.003368 & -3.970790 & 0.0005 \\
\hline LOG(DEP_T_A) & 0.169035 & 0.020766 & 8.139969 & 0.0000 \\
\hline GLP_TA
\end{tabular}

By taking the ROA as dependent variable two variables GLP_TA and Log (DEP_T_A) are significant at $1 \%$ while the D_E is significant negative at $5 \%$ level which means that more the debt in organization it will reduce profitability. The regression coefficients explain that by increasing $1 \%$ in DEP_T_A will bring negative change in ROA by $0.01 \%$. But the $1 \%$ change in GLP TA will bring $16 \%$ change in ROA. Moreover the ROA will remain unchanged by $1 \%$ change in D E. The variation explained by independent variable in dependent variable is $68 \%$ as R2 is .680086 . The fitted most is good due to the $\mathrm{p}$ value significance. The negative sign of coefficients D_E and DEP_T_A shows that the more debt in MFI's the less will be the profitability and in the same manner the more the deposits in institution will reduce the profitability. But the more the GLP from asset will increase the profitability if institution. Since the $\mathrm{H} 1$ hypothesis is accepted that due to change in D_E and DEP_T_A and GLP_TA affects the financial performance of MFI's in Pakistan. H2: Sustainability is significantly affected by debt to equity $(\mathrm{H} 2 \mathrm{a})$, D A $(\mathrm{H} 2 \mathrm{~b})$, GLP_A (H2c).

Table 6

Dependent Variable: LOG (OSS) Method: Panel EGLS (Cross-section random effects))

\begin{tabular}{|c|c|c|c|c|}
\hline Variable & Coefficient & Std. Error & t-Statistic & Prob. \\
\hline \multicolumn{5}{|c|}{0.000004} \\
\hline R- Squared = & \multicolumn{4}{|c|}{0.634276} \\
\hline $\mathrm{C}$ & 0.252296 & 0.046861 & 5.383917 & 0.0000 \\
\hline D_E & -0.008903 & 0.010022 & -0.888361 & 0.3822 \\
\hline LOG(DEP_T_A) & -0.062288 & 0.024223 & -2.571479 & 0.0160 \\
\hline GLP_TA & 0.284305 & 0.038226 & 7.437425 & 0.0000 \\
\hline
\end{tabular}


By taking operational self sufficiency as dependent variable after the log transformation the variation explained by independent variable in dependent variable is $63 \%$ and the fitted model is best fit at 5\%. DEP_T_A is negatively significant which means that more deposits in MFI's will decrease the operational self sufficiency. And the more GLP_TA will increase the operational self sufficiency. D_E is not significant in the case of OSS. In this case significant regression coefficients shows that $1 \%$ change in DEP_T_A and GLP_TA will brings negative change of $.06 \%$ and positive change of $28 \%$ respectively.

Table 7

Dependent Variable: FSS Method: Panel EGLS (Cross-section random effects))
\begin{tabular}{|l|c|r|r|l|}
\hline Variable & Coefficient & Std. Error & \multicolumn{1}{|c|}{ t-Statistic } & Prob. \\
\hline Prob[F-stat] = 0.021378 & & \\
\hline R- Squared = & 0.392136 & & \\
\hline C & 1.160522 & 0.196601 & 5.902927 & 0.0000 \\
\hline D_E & 0.132093 & 0.055886 & 2.363614 & 0.0289 \\
\hline LOG(DEP_T_A) & -0.450811 & 0.718378 & -0.627540 & 0.5378 \\
\hline GLP_TA & 0.242189 & 0.181430 & 1.334888 & 0.1977 \\
\hline
\end{tabular}

The dependence of dependent variable by independent variable is $39 \%$. The D_E is positively significant which means that the more debt in firm will increase the FSS by $13 \%$. While other two variables are found to be in significant however the model is best fit. Since H2 is partially accepted as some of the variables was insignificant in case of FSS.

H3: Financial performance is significantly affected by debt to equity (H3a), D_A (H3b), GLP_A (H3c).

Table 8

Dependent Variable: $N A B^{\wedge} 2$ (Method: Panel EGLS (Cross-section random effects))

\begin{tabular}{|l|r|r|r|l|}
\hline Variable & Coefficient & Std. Error & \multicolumn{5}{|l|}{ t-Statistic } & Prob. \\
\hline Prob[F-stat] $=$ & 0.000000 & \\
\hline R-Squared $=$ & 0.989846 & & \\
\hline C & $-4.22 \mathrm{E}+10$ & $2.17 \mathrm{E}+10$ & -1.941202 & 0.0652 \\
\hline D_E & $-3.08 \mathrm{E}+09$ & $2.94 \mathrm{E}+09$ & -1.047063 & 0.3064 \\
\hline LOG(DEP_T_A) & $6.67 \mathrm{E}+10$ & $2.95 \mathrm{E}+10$ & 2.263051 & 0.0338 \\
\hline GLP_TA & $2.61 \mathrm{E}+11$ & $4.43 \mathrm{E}+10$ & 5.898162 & 0.0000 \\
\hline
\end{tabular}

Above table shows that variation explained by independent variable in dependent variable is very strong at $99 \%$ only $1 \%$ variation is not explained. And the DEP_T_A is positively significant as its p-value is less than $5 \%$ which means that more the deposits out of assets will increase the number of active borrowers in MFI,s. Moreover the gross loan portfolio out of assets will increase the number of active borrowers in firm.

\begin{tabular}{|l|r|r|r|l|}
\hline Variable & \multicolumn{1}{|l|}{ Coefficient } & \multicolumn{1}{|l|}{ Std. Error } & \multicolumn{1}{|l|}{ t-Statistic } & Prob. \\
\hline Prob[F-stat] $=$ & 0.000000 & \\
\hline R- Squared $=$ & 0.989846 & \multicolumn{5}{|l|}{} \\
\hline C & $8.81 \mathrm{E}+08$ & $1.07 \mathrm{E}+09$ & 0.820674 & 0.4220 \\
\hline D_E & -81130478 & $1.41 \mathrm{E}+08$ & -0.576309 & 0.5712 \\
\hline LOG(DEP_T_A) & $5.00 \mathrm{E}+09$ & $2.78 \mathrm{E}+09$ & 1.801005 & 0.0876 \\
\hline GLP_TA & $9.14 \mathrm{E}+09$ & $4.04 \mathrm{E}+09$ & 2.263951 & 0.0355 \\
\hline
\end{tabular}

Here the model is significant at $5 \%$ but the individual probability value of three independent variables are significant at different levels like DEP_T_A is significant at 10\% and GLP is significant at 5\% while D_E is not significant. Except of D_E other two variables has positive relationship with women borrowers which means that more these two ratios will increase the number of women borrowers. The regression coefficients explain that by increase of $1 \%$ in DEP_T_A and GLP_TA will bring a slight change in number if active borrowers. Hence the hypothesis is partially accepted due to insignificance of variables in two different dimensions.

\section{Discussion}

The decision regarding the capital structuring depicts wide range of important points. As we need some combination through which MFI's can better move towards the outstanding performance. We have to be clear about it that either the financial institutions are moving towards the institutional approach or not (khan, 2010). The institutional approach is towards the profitability and further leads towards performance of firm.

According to Consultative Group to assist the poor 2007, presently MFI's are using more funding which can be base to offer more diversified products for the betterment of performance in the sophisticated environment.

The "Critical Microfianncing Triangle" is specially designed to see the aspects the profitability and performance which are Financial susutainbility, outreach to the poor and social impact from which many indicators in this study are showing the similar aspects for the determination of different factors that can leads towards the performance of MFI's (Meyer, 2002).

The regression result shows that leverage has negative impact on financial performance for which proxies are ROA and ROE are negative and not contrast by different studies like (Kyereboah-Coleman, 2007; Abrar \& Javaid, 2016) who said that there is positive relation among debt and performance of the firm. And some studies found that there is negative relation among the profitability and capital structure like (Freind \& Lang, 1988; Shyam-Sunder \& Mayers, 1999). It contarcdicts the trade off theory that company manangers like if there will be more percentage of debt over equity.

Modigillani miller says that firm performance has nothing to do with the formation of capital structure but in the real market, however the Pakistan's economy is not developed it takes time to absorb positive things in it and due to the complex structure of ecomnomy like there are different mind levels which may don't want to move towards any banking sector or loaning sysytem, people are not awared from the sysytems.

More deposits in to the total assets of the firm and Gross loan portflio out of total assets increase the performance of the firm as if there will be more deposits it will incresae the profitability of firm

This study is alingned with the study of Hermes \& Lensink, (2011) who said that increase number of women borrewers will increase the profitability of the firm. While the measure of susustainbility the operational self sufficiency and Financial self suffiency is also significant which means that higher the efficiency will leads towards more profitability. The overall findings indicate that there is no single parameter which can be the only part of the performance there should be misture of different aspect in the capiatl structure of firm for the better performance and it goes alined with the findinding of other research work like (Addae, Nyarko-Baasi, \& Hughes, 2013).

From this study it can be recommended that there should be more deposits rather than more debt in the equity for the 
susutainability of MFI's. And this study was helpul in understanding the capital structure of the MFI's. While unbalanced data was the limitation of the study. Researcher was unable to find the data on short term det and long term debt. After accepting the limitaion reseracher is in opinion to further study about the impact of short term debt and long term debt on the performance of MFI's in Pakistan.

\section{Conclusion}

After the seminal paper of M.M in 1958 several work has been done on the impact on of capital structure towards the performance of entities but MFI are specially less included in research paper in Pakistan. But considering it imporatnt factor it is imporatnt to know the crirtical factors of capital structure which leads towards the performance of MFI's. The main contribution of this study is to take Pakistan MFI's as sector and taking data of almost all of them from (2010-2014) by using the Panel data techinque. The result shows that more deposits to total assets, more gross loan portfolio to total assets, OSS and FSS leads towards the performance of firms. But the more debt in organization may not be profitable as may be the cost of debt was reducing the profit. And the women borrowers and active borrowers are also taking part in the performance.

\section{References}

i. Abrar, A., \& Javaid, A. Y. (2016). The impact of Capital Structure on the profitability of Microfinance insitutions. South Asia Joural of Manangement Sciences, 10(1), 21-37.

ii. Addae, A. A., Nyarko-Baasi, M., \& Hughes, D. (2013). The Effects of Capital Structure on Profitability of Listed Firms. European Journal of Business and Management, 5(31), 2222-2839.

iii. Fehr, D. (2006). raising Capital of Micro finance: Sources of fundings and opportunities forequity financing. Journal of Developmental Entrepreneurship, 11(02), 133-143.

iv. Freind, I., \& Lang, L. H. (1988). the Impact of Managerial Self-Interest on Corporate Capital Structure. The Journal of Fiannace, 43(2), 271-281.

v. Ganesha, S. (2007). Microfinance: Panacea for all economic ills? Lestangents.

vi. Goodman, P. (2008). Raising MFI Equity Through Microfinance. Springer, 1-31.

vii. Hermes, N., \& Lensink, R. (2011). Microfinance: Its Impact, Outreach, and Sustainability. Science direct, 39(6), 875-881.

viii. huberman, M. (1994). Conceptual Framework. Sage, 39-72.

ix. Ismail, A. G., \& Possumah, B. T. (2012). Does the Capital Structure Matter for Islamic Microfinance Institutions? Jeddah 21413, Kingdom of Saudi Arabia: Islamic Research and Training Institute.

x. khan, A. A. (2010). Analysis of Critical factors of Microfinance insitutions of Pakistan. Paradigms, 4(1), 2447.

xi. Kyereboah-Coleman, A. (2007). Corporate governance anf firm performance in ghana. Legon: International Conference on Corporate Governance in Emerging.

xii. Leon, S. A. (2013). The impact of Capital Structure on Financial Performance of the listed manufacturing firms in Sri Lanka. Global Journal of commerce and Management Prespective, 56-62.

xiii. Mayers, s. c. (1984, April 17). Capital structure Puzzle. Capital structure Puzzle, pp. 1-35

xiv. Meyer, R. L. (2002). Track Record of Financial Institutions in Assisting the Poor in Asia. ADB INSTITUTE RESEARCH PAPER 49.

xv. Miller, Modigillani, F., \& H, M. (1958). The cost of capital, Corporation finance. The American Economic Review, 261297.

xvi. Morduch, J. (2000). The Microfnance Schism. pergamon, $617 \pm 629$.

xvii. Robinson, M. (2001). The Microfinance Revolution: Sustainable finance for the poor. The World Bank, xlvii, 304.

xviii. Ronoh, C. (2015). Effects of Capital stucture on performance of listed commercials banks in Kenya. the strategic Journal of Business \& change Management, 750781. xix. Rub, A., Suleiman, D., Abbadi, M., \& Nour, D. (2012). The Effect of Capital Structure on the Performance of Palestinian Financial Institutions. British Journal of Economics, Finance and Management Sciences, 92-101.

xx. Shyam-Sunder, L., \& Mayers, S. C. (1999). Testing static tradeoff against pecking order models. Journal of Financial Economics, 51, 219-244. 